\title{
Determining factors impacting the application of IFRS in teaching: Evidence from Vietnam
}

\author{
Tran Hanh Phuong Le ${ }^{a}$, Thi CamThanh Tran ${ }^{a}$, Thi Le Hang Nguyen ${ }^{a}$, Nhat Minh Dao ${ }^{a}$, Nu Mai \\ Quynh Ngo a and Ngoc Tien Nguyen ${ }^{a^{*}}$
}

\begin{tabular}{l}
${ }^{\text {a }}$ Faculty of Economics and Accounting \\
\hline C H R O N I C L E \\
\hline Article history: \\
Received August 25, 2021 \\
Received in revised format \\
September 282021 \\
Accepted November 12021 \\
Available online \\
November 22021 \\
\hline Keywords: \\
Applying IFRS in teaching \\
Accounting \\
Auditing \\
IFRS \\
Vietnam \\
\end{tabular}

\author{
Nhon University, BinhDinh, Vietnam

\section{A B S T R A C T}

With the aim of determining the factors affecting the application of IFRS in teaching for universities and colleges with accounting and auditing training, the research was conducted at 30 universities, colleges with accounting and auditing majors, and 208 lecturers who are engaged in teaching accounting and auditing in Vietnam. Next, the study employed the method of regression analysis by PLS_SEM software to process and analyze the collected data. Research results show that eight factors are affecting the application of IFRS in teaching at universities and colleges in Vietnam in the order of influence from high to low, respectively (i) Training program; (ii) Teaching staff; (iii) Regulation on the application of IFRS of the Ministry of Finance; (iv) Request of the related parties; (v) Faculty/Institution administrators; (vi) Teaching aids; (vii) IFRS teaching methods and (viii) Learners (students, trainees). At the same time, the study also shows that the financial capability of the institutions does not affect the application of IFRS in teaching.

\section{Introduction}

With the trend of integration and convergence with international accounting, creating a legal corridor on accounting to attract businesses and foreign investors to Vietnam, Vietnam's Ministry of Finance has issued Decision No. 345/QD-BTC approving the roadmap for IFRS application in Vietnam. According to this roadmap, in addition to the work that businesses need to prepare to apply IFRS to accounting and financial statement presentation, the issue of training human resources in accounting and auditing in universities and colleges in Vietnam to meet the requirements of the IFRS application roadmap of the Ministry of Finance is also considered to have a very crucial and indispensable part to play. On that basis, as places to train accounting human resources for businesses, universities and colleges offering accounting and auditing training in Vietnam need to transform the content of accounting and auditing training programs from purely leaning towards the Law on Accounting, Accounting Standards and Vietnam's corporate accounting regime to applying International Accounting Standards (IAS) and IFRS in the teaching process. However, the application of IAS and IFRS (collectively referred to as IFRS) in teaching accounting and auditing at universities and colleges in Vietnam has been facing many difficulties and challenges, including fostering knowledge about IFRS for lecturers, rebuilding training programs, compiling and translating learning materials, investing in IFRS-related facilities, etc., to serve the teaching and learning of IFRS for lecturers, students, and trainees. Stemming from the issues above, this study was conducted to determine the factors affecting the application of IFRS in teaching accounting and auditing majors of universities and colleges in Vietnam. Thereby, solutions are proposed to empower the institutions to apply IFRS in teaching conveniently and effectively. The structure of the research paper

* Corresponding author.

E-mail address: nguyenngoctien@qnu.edu.vn (N. T. Nguyen)

(C) 2022 Growing Science Ltd. All rights reserved.

doi: $10.5267 /$ j.ac.2021.11.001 
consists of five parts; the following part is the literature review, the third part deals with the research methodology, the fourth part is concerned with the research results, the fifth part revolves around discussion and solutions, and the sixth part is the conclusion.

\section{Literature Review}

Regarding determining the factors affecting the application of IFRS in different types of businesses, there have been many studies conducted such as those by Parvathy (2017), De Lima et al. (2018), Tran et al. (2019), Ta et al. (2021), Al-Shetwi (2021), Al-Sakini et al. (2021), etc. It can be said that each study has certain contributions and has pointed out many factors that impact the application of IFRS to businesses. In the field of education, the application of IFRS in teaching has also been the topic for several studies; each research depends on a different perspective and puts forward statements, views, assessments as well as different implications and recommendations, typically:

Dow and Feldman (1997) argue that to teach IFRS effectively, it is necessary to teach in small numbers, apply the case method, and focus on specific case handling related to IFRS. Furthermore, it takes time to develop the teaching content. In the same vein, Hilton and Johnstone (2013) also point out the fact that time constraints prevent them from adding real-life situations and contents to their curricula when teaching IFRS. Munter and Reckers (2009) state that developing IFRS-related teaching materials is very difficult, and $72 \%$ of the lecturers surveyed for the study said that teaching IFRS in the curriculum faced many challenges, or the study of Zhu et al. (2011) shows that IFRS standards need to be mentioned more regularly in the curriculum as lecturers are increasingly appreciating the convergence between IFRS and US GAAP. Research results show the difficulty of lecturers when applying IFRS in teaching because IFRS documents are still very limited. At the same time, Garnett (2011) asserts that when teaching IFRS in the classroom, accounting lecturers need to ensure that their students understand the nature of IFRS, identify the relevant IFRS principles and requirements, consider alternative accounting methods when recording accounting data to reach consensus on the principles of recording, explaining the application of IFRS in practice. This process has helped to change the teaching methods of lecturers and improved students' initiative and activeness in the process of approaching reality. Sharing the same view, Hilton and Johnstone (2013) state that the application of IFRS in teaching has motivated accounting lecturers to re-examine the teaching approach and module contents. On that basis, the lecturers begin to focus more on teaching according to accounting concepts and principles instead of the previous professional accounting; moreover, Canadian accounting standards have many similarities with IFRS, so changing the new direction in the teaching practice of the lecturers has brought more efficiency. The study by Jackling et al. (2013) on the impacts of the transition to IFRS teaching in Australia shows the relation to the teaching methods in undergraduate accounting classes. The results show that the application of IFRS in teaching has led to changes in the curricula and teaching methods of lecturers at universities. Besides, the study of Alzeban (2016) is based on the model of Beasley et al. (2005) to investigate the impact of a lecturer's attitude, size of accounting faculty, communication ability, type of organization, teaching experience and teaching materials on the length of IFRS instruction in the curriculum. The results indicate that the attitude of the instructors and the availability of IFRS materials have the greatest impact on the time spent teaching IFRS. In addition, the support of the departments such as the library, the training management department, and the experience of training and teaching on IFRS also have a positive influence. Along the same line of research, Kang (2016) shows that public institutions are more advanced than private institutions in applying IFRS to the curriculum. In addition, strengthening the accounting faculty and reducing the budget are important factors affecting the application of IFRS in teaching. Additionally, the study by Joshua (2017) on changes in accounting curriculum for US college students when teaching IFRS shows that progress is not evenly spread across different regions in the US. The authors propose solutions to help improve the quality of training of the workforce that can meet the requirements of international accounting integration in the future. In the same direction of this study, Nanyan et al. (2019) on assessing learning effectiveness when IFRS is applied in teaching, reveals that when the institutions apply IFRS in teaching, it will help students better adapt to and better perform in ACCA global exams at both basic and professional levels. This result has significance for IFRS education in non-English speaking countries.

In Vietnam, since the Ministry of Finance issued a roadmap to apply IFRS, educational managers and lecturers of universities also have had researches and proposals from different angles to bring IFRS into teaching, typically:

Tran Manh Dung and Nguyen Thuy Hong (2016) present comments and challenges that accounting lecturers face when teaching IFRS standards in Vietnam. Specifically, the authors have pointed out the difference between accounting standards based on IFRS principles and accounting standards based on current VAS rules, and this distinction has a significant impact on accounting training. Meanwhile, Nguyen Cuu Dinh (2017), Le The Anh (2017) all suggest that to improve the quality of the accounting workforce through training institutions in the current context of deep integration, one of the most important measures is to orient learners to understand the nature of economic activities and to creatively apply accounting principles according to IFRS. And Trinh Duc Vinh (2019), in a study on skills and knowledge that accountants need to be equipped to meet the requirements of accounting innovation in Vietnam, shows that the renaming of international standards is not simply a name change for a system of standards, the main point is to emphasize that the purpose of the Standard is to provide information in financial statements, not in accounting records. Therefore, the training and equipping skills for accountants at universities need to be changed; bookkeeping skills (making accounting entries), tax declaration still play a secondary role supporting the main purpose of accounting work. 
Pham Thi Tuyet Minh (2019) points out that training curricula at many universities in Vietnam need to be innovated, built on the principles of the essence of the problem, avoiding building curriculum contents that depend too much on the provisions of the legal documents. The research aims to integrate the content of specialized subjects with training programs of international associations such as the Association of Chartered Certified Accountants (ACCA), the Vietnam Association of Accountants and Auditors (VAA), the Vietnam Association of Accountants and Auditors (VAA), Vietnam Association of Certified Public Accountants (VACPA), etc. Sharing the same view, Tran Thi Hong Van (2020) points out that universities, academies, colleges offering training in accounting and auditing currently have no systematic training program on IFRS, so it is necessary to have a standard IFRS training program among the institutions and harmonize with the teaching of national accounting standards.

From the review of the above studies, it is essential to change the teaching of accounting and auditing according to IFRS for universities and colleges in Vietnam in the current context to meet the requirements of society, businesses, regulations of the Ministry of Finance and the convergence trend of accounting in the context of economic integration. However, the studies have mainly looked at the qualitative aspect and have not covered all the factors affecting the application of IFRS in teaching accounting and auditing at universities and colleges.

\section{Research Methodology}

\subsection{Research procedure}

To carry out this study, the authors followed research steps illustrated through the following diagram:

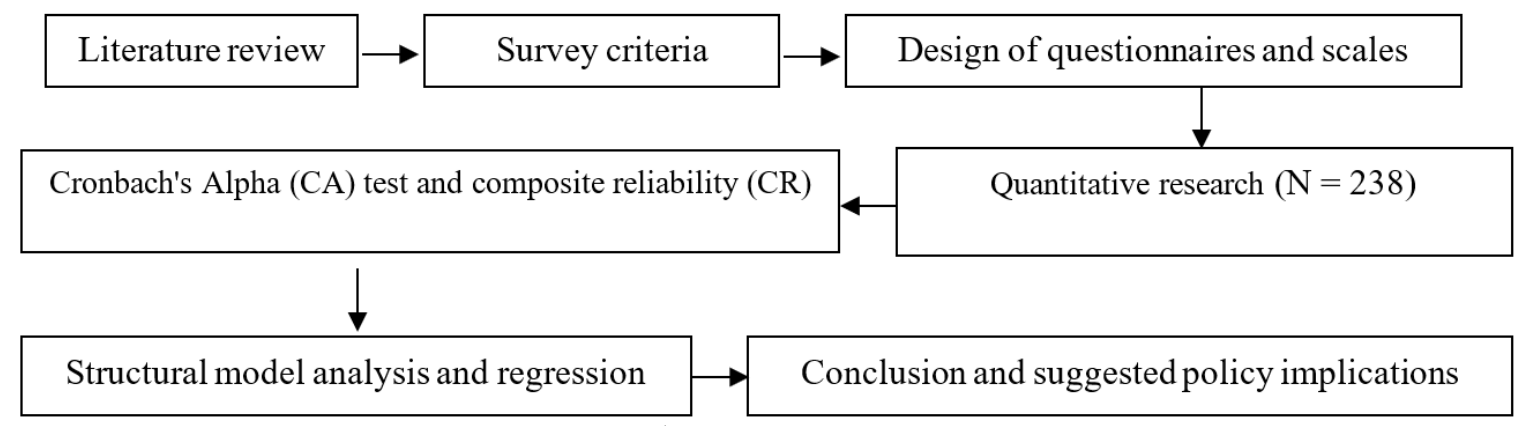

Fig. 1. Research procedure

\subsection{Research Hypotheses}

\section{Teaching methods for IFRS training $\left(X_{-} 1\right)$}

The teaching method is understood as the way, the general interaction between lecturers and learners in a certain teaching condition, to achieve the objectives of the training. Chiang (2014) states that the teaching method involving case handling and active teaching has a great influence on the learning efficiency of students; accordingly, assignments should be personalized to allow students to choose their area of interest and apply accounting concepts. The study also recommends that lecturers should formulate questions for students to answer based on the materials provided and mentioned, which will increase students' feedback and interaction with lecturers. At the same time, Bruns (2014) argues that many accounting models can be used to achieve integration, including teaching-related topics in a course, teaching in groups and designing a whole curriculum revolving around business and accounting cases. This method is very effective but requires lecturers to spend a lot of time developing and preparing teaching materials. Sharing the same opinion on teaching methods that affect teaching effectiveness, there are also studies by Belyaeva (2019), Mkhongi (2020), Seifan (2020), El-Ariss(2021), etc.

Hypothesis $\mathbf{H}_{1}$ : Teaching methods have an influence on the application of IFRS in teaching accounting and auditing.

\section{Regulations of Ministry of Finance on the application of IFRS (X_2)}

Regulations are promulgated by the State in order to harmonize the rights and responsibilities of each citizen and every organization in the social order, towards the harmonization of the community's interests; these are the principles that define social relationships, shape the behaviour of members of society and regulate the functioning of society. Accordingly, Trinh Duc Vinh (2019) believes that when the Ministry of Finance promulgates regulations on the application of IFRS, it will be a legal basis for training institutions to transform training programs of accounting and auditing for complying with the regulations. Similarly, there are studies by Tran et al. (2019), Pham Thi Tuyet Minh (2019), etc. 
Hypothesis H2: Regulations of the Ministry of Finance on the application of IFRS influence the application of IFRS in teaching accounting and auditing majors.

\section{Faculty/ Institution administrators (X_3)}

According to the 2018 modified Education Law (National Assembly, 2018), the function of higher education institutions is to perform the training of higher education levels, scientific and technological activities, serving the community. Accordingly, the faculty-level administrator is the head manager of the specialized faculties in the university, while the institution-level administrator is the head of the higher education institution, responsible for the management and explaining to the society about the training activities in the school. Turhan (2018) when studying the course of actions to handle conflict, suggests that when the institution administrators are bold in employing new teaching methods, the innovation of the courses' contents will promote the training efficiency. With this same point of view, Convey (2012) also argues that the views of the administrators have a significant influence on the transformation in teaching and learners' beliefs.

Hypothesis $\mathbf{H}_{3}$ : Faculty/Institution administrators have an influence on the application of IFRS in teaching accounting and auditing majors.

\section{Training programs (X_4)}

A training program is a system of educational and training activities designed and organized to achieve training objectives, towards the granting of an educational diploma to learners. The training program includes objectives, knowledge volume, structure, content, methods and assessments for modules, majors, training levels, and learning outcomes following the national qualification framework (Ministry of Education and Training, 2021). Studies by Susan (2020), Fogarty and Jonas (2019) all show that the management of a study program includes the quality and quantity of students, enrollment, development of formal and extracurricular programs, measurement of the program's quality, methods of assessing learners, the performance of training-support departments, accrediting training programs, etc., exerting an impact on the quality of accounting training.

Hypothesis $\mathbf{H}_{4}$ : The training program has an impact on the application of IFRS in teaching accounting and auditing majors.

\section{Teaching aids (X_5)}

In education in general and schools in particular, the term teaching aids is understood to refer to all the means and equipment for the teaching process such as facilities, teaching medium, teaching equipment, school equipment, learning tools, visual aids, documents, learning materials, etc. Research by Robert and Donna (2011) shows that accountants, educators and students are in dire need of IFRS teaching materials. In addition to focusing on IFRS teaching materials in English, the research recommends helpful materials which are available in other languages. At the same time, the studies by Munter and Reckers (2009), Alzeban (2016), Nanyan et al. (2019) also show that teaching means and teaching equipment influence teaching methods and training effectiveness.

Hypothesis Hs: Teaching aids have an impact on the application of IFRS in teaching accounting and auditing majors.

\section{Learners (students, trainees) (X_6)}

For universities and colleges, learners are people who are studying and doing scientific research at universities, including students and trainees of undergraduate programs, students of the master's program, doctoral students of doctoral training programs. Research by Krasodomska and Godawska (2021), Mellado et al. (2020), Braun et al. (2020) reveal that issues of gender, age, nationality, academic expertise, personal work interests, attitudes and learning behaviours, etc. have an influence on the accounting learning process in general and learning IFRS in particular for learners.

Hypothesis $\mathbf{H}_{6}$ : Learners (students, trainees) have an influence on the application of IFRS in teaching accounting and auditing majors.

\section{Institution's financial ability (X_7)}

The financial ability of the institution is understood as the capacity of securing financial resources for the institution's activities in order to achieve the training objectives set by the institution. Research by Eric (1996), Rouse et al. (2009), Valenzuela et al. (2013), Rothstein (2017), etc., all suggest that the investment in improving the professional qualifications of the lecturers, building a document/learning material system, creating the information technology infrastructure and an electronic database for the training purpose have a significant impact on the training efficiency of the institutions. 
Hypothesis H7: The financial ability of the institution have an influence on the application of IFRS in teaching accounting and auditing majors.

\section{Teaching staff (X_8)}

For higher education, the teaching staff is understood as lecturers who are responsible for teaching and doing scientific research at higher education institutions, having professional qualifications as prescribed for each training level, being trained and fostered in pedagogical skills according to prescribed standards, having a clear identity, having good moral qualities, being eligible to participate in teaching; being possibly invited to teach at other universities. Research by Tran Manh Dung and Nguyen Thuy Hong (2016), Trinh Duc Vinh (2019), Szwarc (2020), López-Díaz (2021), Tami (2021), etc. all believe that the initiative, positivity, the lecturers' experience, combined with their knowledge and understanding of the profession and of the practice have a great influence on the training effectiveness of higher education institutions.

Hypothesis Hs: The teaching staff have an influence on the application of IFRS in teaching accounting and auditing majors.

\section{Requirements from related parties (X_9)}

Parties are considered to be related if one party can control or exercise significant influence over the other party in making financial and operational decisions. Studies by Freeman (1984), Thomas and Lee (1995), Mitchell et al. (1997), Bourne and Walker (2005), Bruce et al. (2008), Ackermann and Eden (2011) all point out that related parties have the right to propose and request legal and urgent requirements for suppliers of products, goods and service in general and other related issues.

Hypothesis $\mathbf{H}_{9}$ : Requirements from related parties have an impact on the application of IFRS in teaching accounting and auditing majors.

\subsection{Research Model}

Based on research hypotheses, the authors proposed a research model that is a multivariable regression model with the dependent variable of applying IFRS to teaching accounting and auditing and the nine independent variables mentioned in each hypothesis of the study, as follows:

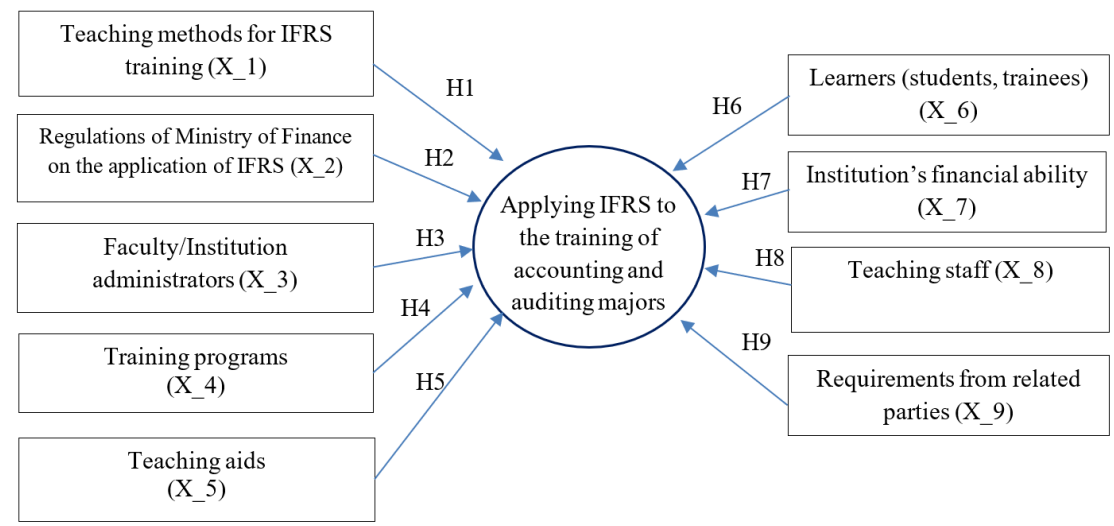

Fig. 2. Overview of the research model

From the above-proposed model, the authors put forward the expected research equation as:

$\mathrm{Y}=\alpha+\beta 1 * \mathrm{X} \_1+\beta 2 * \mathrm{X} \_2+\beta 3 * \mathrm{X} \_3+\beta 4 * \mathrm{X} \_4+\beta 5 * \mathrm{X} \_5+\beta 6 * \mathrm{X} \_6+\beta 7 * \mathrm{X} \_7+\beta 8 * \mathrm{X} \_8+\beta 9 * \mathrm{X} \_9+\varepsilon$

where:

$\alpha, \beta 1, \beta 2, \beta 3, \beta 4, \beta 5, \beta 6, \beta 7, \beta 8$ and $\beta 9$ are coefficients

$\varepsilon$ : is error

\subsection{Variables of the Research Model}

To serve the process of compiling questionnaires and collecting the data, the authors use the Likert scale ( 5 options), the rating levels according to this scale are as follows: 1 - Strongly disagree; 2 - Disagree; 3 - Neutral; 4 - Agree; 5 - Strongly agree. The variables and scales of the research model are determined as follows: 
Table 1

Variables and scales employed

\begin{tabular}{|c|c|c|c|}
\hline $\begin{array}{l}\text { Order Factors } \\
\text { Dependent variable }\end{array}$ & Observed variables & Encryption & \multirow{4}{*}{$\begin{array}{c}\text { Source } \\
\text { Trinh Duc Vinh (2019); } \\
\text { Tran et al. (2019); Belyaeva } \\
\text { (2019); Fogarty \& Jonas } \\
\text { (2019); }\end{array}$} \\
\hline \multirow{8}{*}{$\begin{array}{l}\text { Applying IFRS to } \\
\text { the training of } \\
\text { accounting and } \\
\text { auditing majors } \\
\text { (Y) }\end{array}$} & Renovating or updating accounting and auditing training programs. & Y_1 & \\
\hline & $\begin{array}{l}\text { Establishing/adding learning outcomes related to IFRS knowledge for accounting and } \\
\text { auditing training programs. }\end{array}$ & Y_2 & \\
\hline & Training/Updating knowledge about IFRS for teaching staff. & Y_3 & \\
\hline & $\begin{array}{l}\text { Consulting with stakeholders (employment agencies, alumni, professional associations, etc.) } \\
\text { about the contents of IFRS to be taught. }\end{array}$ & $\mathrm{Y}_{-} 4$ & \multirow{5}{*}{$\begin{array}{c}\text { Nanyan et al. (2019); } \\
\text { Mkhongi (2020); Seifan } \\
\text { (2020); EL-Ariss(2021); } \\
\text { Susan (2020); } \\
\text { Braun et al. (2020); } \\
\text { Szwarc (2020); López-Díaz } \\
\text { (2021) and surveyed experts }\end{array}$} \\
\hline & $\begin{array}{l}\text { Collecting/Updating/Standardizing documents (lectures, textbooks, reference books, } \\
\text { monographs) related to IFRS for teaching purposes }\end{array}$ & Y_5 & \\
\hline & $\begin{array}{l}\text { Orienting/encouraging trainers to select appropriate teaching methods to convey the contents } \\
\text { of IFRS to learners }\end{array}$ & Y_6 & \\
\hline & $\begin{array}{l}\text { Investing in facilities, information technology infrastructure, databases/learning materials to } \\
\text { serve teaching/learning for lecturers/students }\end{array}$ & Y_7 & \\
\hline & $\begin{array}{l}\text { Coordinating with professional associations and organizations (such as ACCA, SmartTrain, } \\
\text { VAA, VACPA, etc.) to jointly support the process of applying IFRS to teaching. }\end{array}$ & Y_8 & \\
\hline
\end{tabular}

\begin{tabular}{|c|c|c|c|c|}
\hline \multicolumn{5}{|c|}{ Independent variables } \\
\hline \multirow{5}{*}{1} & \multirow{5}{*}{$\begin{array}{l}\text { Teaching methods } \\
\text { for IFRS training } \\
\qquad\left(X_{-} 1\right)\end{array}$} & $\begin{array}{l}\text { The selection of appropriate teaching methods for each learner has a positive impact on the } \\
\text { teaching of IFRS }\end{array}$ & X_11 & \multirow{5}{*}{$\begin{array}{c}\text { Chiang (2014); } \\
\text { Bruns (2014); } \\
\text { Belyaeva (2019); Mkhongi } \\
\text { (2020); Seifan (2020); EL- } \\
\text { Ariss(2021) } \\
\text { and surveyed experts }\end{array}$} \\
\hline & & The methods of presentation and suggestive problem-solving are suitable for teaching IFRS & X_12 & \\
\hline & & Active teaching methods suitable for IFRS teaching & $X \_13$ & \\
\hline & & The case-based teaching method is suitable for teaching IFRS & $\mathrm{X}_{-} 14$ & \\
\hline & & $\begin{array}{l}\text { The combination of many methods in teaching will enhance the teaching effectiveness of } \\
\text { IFRS }\end{array}$ & X_15 & \\
\hline \multirow{3}{*}{2} & \multirow{3}{*}{$\begin{array}{l}\text { Regulations of } \\
\text { Ministry of } \\
\text { Finance on the } \\
\text { application of } \\
\text { IFRS (X_2) }\end{array}$} & $\begin{array}{l}\text { Regulations of the Ministry of Finance on applying IFRS to businesses have prompted } \\
\text { universities and colleges in Vietnam to apply IFRS in teaching }\end{array}$ & X_21 & \multirow{3}{*}{$\begin{array}{c}\text { Trinh Duc Vinh (2019); } \\
\text { Tran et al. (2019); } \\
\text { Pham Thi Tuyet Minh } \\
\text { (2019); Tran Thi Hong Van } \\
\text { (2020) and surveyed experts }\end{array}$} \\
\hline & & $\begin{array}{l}\text { Regulations on the roadmap for applying IFRS to businesses are the basis for universities and } \\
\text { colleges in Vietnam to determine the timelines for applying IFRS to teaching }\end{array}$ & X_22 & \\
\hline & & $\begin{array}{l}\text { Regulations on the roadmap for applying IFRS to businesses are the basis for universities and } \\
\text { colleges in Vietnam to orient IFRS-related contents to be taught in modules of training } \\
\text { programs of accounting and auditing majors }\end{array}$ & X_23 & \\
\hline \multirow{3}{*}{3} & \multirow{3}{*}{$\begin{array}{l}\text { Faculty/Institution } \\
\text { administrators } \\
\qquad\left(X_{-} 3\right)\end{array}$} & $\begin{array}{l}\text { Faculty/Institution administrators who wish to apply IFRS into teaching accounting and } \\
\text { auditing can have a positive impact on the application of IFRS }\end{array}$ & X_31 & \multirow{3}{*}{$\begin{array}{l}\text { Turhan (2018); Convey } \\
\text { (2012); Trinh Duc Vinh } \\
\text { (2019) and surveyed experts }\end{array}$} \\
\hline & & $\begin{array}{l}\text { Faculty/Institution administrators need to support and create favourable conditions for the } \\
\text { application of IFRS in teaching accounting and auditing }\end{array}$ & X_32 & \\
\hline & & $\begin{array}{l}\text { Faculty/Institution administrators play an important role in accelerating or slowing the } \\
\text { application of IFRS in teaching accounting and auditing. }\end{array}$ & X_33 & \\
\hline \multirow{4}{*}{4} & \multirow{4}{*}{$\begin{array}{l}\text { Training programs } \\
\quad\left(X_{-} 4\right)\end{array}$} & $\begin{array}{l}\text { The accounting and auditing training programs should involve the design of the modules that } \\
\text { combine both Vietnamese Accounting Standards (VAS) and IFRS to highlight the differences } \\
\text { between VAS and IFRS }\end{array}$ & X_41 & \multirow{4}{*}{$\begin{array}{l}\text { Susan }(2020) \text {; Fogarty } \\
\& \text { Jonas (2019) and } \\
\text { surveyed experts }\end{array}$} \\
\hline & & The modules related to IFRS should be obligatory ones in the training program & X_42 & \\
\hline & & IFRS-related modules are part of the specialized knowledge block of the training program & X_43 & \\
\hline & & It is necessary to incorporate bilingual teaching of IFRS knowledge in the training program & X_44 & \\
\hline \multirow{3}{*}{5} & \multirow{3}{*}{$\begin{array}{l}\text { Teaching aids } \\
\quad\left(X \_5\right)\end{array}$} & $\begin{array}{l}\text { The system of documents/learning materials (lectures, textbooks, reference books, } \\
\text { monographs, etc.) exerts a considerable influence on the application of IFRS into teaching }\end{array}$ & X_51 & \multirow{3}{*}{$\begin{array}{c}\text { Robert \& Donna (2011); } \\
\text { Munter \& Reckers (2009); } \\
\text { Alzeban (2016); Nanyan et } \\
\text { al. (2019) } \\
\text { and surveyed experts }\end{array}$} \\
\hline & & $\begin{array}{l}\text { Information technology infrastructure, electronic databases for self-study/guided self-study } \\
\text { have a significant influence on the effectiveness of IFRS application in teaching }\end{array}$ & X_52 & \\
\hline & & $\begin{array}{l}\text { The diversity of facilities/places for internship/practice influences the application of IFRS in } \\
\text { teaching }\end{array}$ & X_53 & \\
\hline \multirow{4}{*}{6} & \multirow{4}{*}{$\begin{array}{l}\text { Learners } \\
\text { (students, } \\
\text { trainees) (X_6) }\end{array}$} & $\begin{array}{l}\text { The active participation of learners in the IFRS teaching process affects the quality of IFRS } \\
\text { training }\end{array}$ & X_61 & \multirow{4}{*}{$\begin{array}{c}\text { Krasodomska \& } \\
\text { Godawska (2021); Mellado } \\
\text { et al. (2020); Braun et } \\
\text { al. (2020) and surveyed } \\
\text { experts }\end{array}$} \\
\hline & & Learners being able to acquire/absorb the knowledge of IFRS affects the teaching of IFRS & X_62 & \\
\hline & & Learners' self-study/self-research ability (autonomy) affects the IFRS teaching process & X_63 & \\
\hline & & $\begin{array}{l}\text { Learner's English ability influences the process of self-study/self-research of IFRS } \\
\text { knowledge }\end{array}$ & X_64 & \\
\hline \multirow{3}{*}{7} & \multirow{3}{*}{$\begin{array}{l}\text { Institution's } \\
\text { financial ability } \\
\quad\left(X_{-} \text {) }\right.\end{array}$} & $\begin{array}{l}\text { The financial investment for lecturers to participate in IFRS training/retraining courses for } \\
\text { teaching has a crucial influence on the IFRS teaching process }\end{array}$ & X_71 & \multirow{3}{*}{$\begin{array}{l}\text { Eric (1996); Rouse et al. } \\
\text { (2009); Valenzuela et al. } \\
\text { (2013); Rothstein (2017) and } \\
\text { surveyed experts }\end{array}$} \\
\hline & & $\begin{array}{l}\text { The financial investment to build the system of documents/learning materials on IFRS affects } \\
\text { the effectiveness of IFRS teaching. }\end{array}$ & X_72 & \\
\hline & & $\begin{array}{l}\text { The financial investment to create information technology infrastructure and electronic } \\
\text { database for IFRS training affects the effectiveness of IFRS teaching }\end{array}$ & X_73 & \\
\hline \multirow{5}{*}{7} & \multirow{5}{*}{$\begin{array}{l}\text { Teaching staff } \\
\quad\left(X_{-} 8\right)\end{array}$} & $\begin{array}{l}\text { The teaching staff have a desire to apply IFRS in teaching, which affects the effectiveness of } \\
\text { IFRS teaching }\end{array}$ & X_81 & \multirow{5}{*}{$\begin{array}{l}\text { Tran Manh Dung \& Nguyen } \\
\text { Thuy Hong (2016); Trinh } \\
\text { Duc Vinh (2019); Szwarc } \\
\text { (2020); López-Díaz (2021); } \\
\text { Tami (2021) and surveyed } \\
\text { experts }\end{array}$} \\
\hline & & $\begin{array}{l}\text { The initiative and positivity of IFRS lecturers have an impact on the effectiveness of IFRS } \\
\text { teaching }\end{array}$ & X_82 & \\
\hline & & $\begin{array}{l}\text { Lecturers who have sufficient knowledge and understanding of IFRS to carry out IFRS } \\
\text { teaching have an impact on IFRS teaching effectiveness }\end{array}$ & X_83 & \\
\hline & & $\begin{array}{l}\text { Teaching experience to impart IFRS knowledge of lecturers affects the effectiveness of IFRS } \\
\text { teaching }\end{array}$ & X_84 & \\
\hline & & $\begin{array}{l}\text { The lecturer's English ability and presentation skills of IFRS knowledge have a significant } \\
\text { influence on the effectiveness of IFRS teaching }\end{array}$ & X_85 & \\
\hline \multirow{4}{*}{8} & \multirow{4}{*}{$\begin{array}{l}\text { Requirements } \\
\text { from related } \\
\text { parties (X_9) }\end{array}$} & $\begin{array}{l}\text { Social needs (recruitment agencies, professional associations, etc.) influence the application } \\
\text { of IFRS into teaching }\end{array}$ & X_91 & \multirow{4}{*}{$\begin{array}{l}\text { Freeman (1984); Thomas \& } \\
\text { Lee (1995); Mitchell et al. } \\
\text { (1997); Bourne \& Walker } \\
\text { (2005); Bruce et al. (2008); } \\
\text { Ackermann \& Eden (2011) } \\
\text { and surveyed experts }\end{array}$} \\
\hline & & $\begin{array}{l}\text { Learners' needs for future careers and employment opportunities that influence the } \\
\text { application of IFRS into teaching }\end{array}$ & X_92 & \\
\hline & & $\begin{array}{l}\text { The comments/feedback of the alumni/student network have an influence on the application } \\
\text { of IFRS-related knowledge in teaching }\end{array}$ & X_93 & \\
\hline & & Legislative requirements that affect the application of IFRS into teaching & X_94 & \\
\hline
\end{tabular}




\subsection{Methods of Data Collection}

To collect data for the study, the authors used a pre-designed survey form based on the variables and scales identified. The final survey form was built based on 3 stages.

Stage 1, Developing a draft survey questionnaire: the authors conducted an overview of domestic and foreign studies related to the research problem to identify research gaps. Next, the research team delivered a drafted survey questionnaire with survey questions consisting of two parts, specifically: (i) general information about respondents, (ii) survey information.

Stage 2, Expert consultation and experimental investigation to complete the scales, observed variables, etc. to be surveyed: in this stage, the authors conducted direct interviews with experts who are administrators, lecturers at universities and colleges and experts working in professional organizations with the interviews and consultations of 25 people. At this stage, the research team carried out direct interviews about the survey questionnaires designed in Stage 1 and discussed research ideas with experts and lecturers to consider whether the survey questionnaire is appropriate or not, whether it is necessary to supplement or adjust the observed scales and variables accordingly.

Stage 3, Design of the official survey questionnaire: based on the interview results in Stage 2, the authors synthesized and produced a complete survey questionnaire. To increase the effectiveness, accuracy and feasibility of the survey questionnaire, the authors conducted a discussion with the experts to continue to record more opinions of the experts to perfect the final survey questionnaire at its best.

At the same time, the process of surveying 30 universities and colleges and 208 accounting lecturers at the institutions was conducted through interviews, direct surveys, and surveys through Google Form.

\subsection{Methods of Data Analysis}

From the validly collected survey questionnaires, the authors transferred the data to Excel, coding for variables according to each part of the survey questionnaire. Then, all the data was put into PLS-SEM software. In the process of data processing and analysis, the authors employed a number of analytical and testing tools as follows:

First, the authors evaluated the internal consistency reliability through Composite Reliability (CR) and Cronbach's Alpha coefficient (CA). According to Henseler \& Sarstedt (2013), the CR index should reach the threshold of 0.7 or higher, which is suitable for confirmatory research. Many other researchers also agree that a CR index of 0.7 or higher is an appropriate threshold for studies (Hair et al., 2017; Bagozzi \& Yi, 1998). According to Hair et al. (2017), the condition to be accepted for the CA coefficient is that it is supposed to be greater than 0.7. At the same time, according to Devellis (2012), the CA coefficient needs to be 0.7 or more to be acceptable. Therefore, in this study, it is appropriate for the authors to choose a threshold for both coefficients to be 0.7 or more.

Second, the authors evaluated the convergence value through the average variance extracted (AVE). This is to ensure AVE is greater than 0.5. (Chin, 2010; Hair et al., 2014, 2017, 2019).

Third, the authors conducted the discriminant value evaluation. The purpose of this analysis step is to show the distinctiveness of a structure from other structures in the model. The Fornell-Larcker criteria are the first way to assess discriminant value. In this way, discriminability is ensured when the square root of the AVE of each variable must be greater than its correlation coefficient with other variables (Fornell \& Larcker, 1981). Recently, Henseler et al. (2015) proposes to evaluate the discriminant value through the HTMT index (Heterotrait-Monotrait ratio). Accordingly, this HTMT index value must be less than 0.9 to ensure the discrimination between the two research variables (Hair et al., 2019).

Fourth, the author tested the research hypotheses: Testing the hypotheses about the direct relationship through the path coefficient $\beta$ and the p-value of the t-test (student test). Specifically: After PLS-SEM is run, the path coefficient ( $\beta$ ) represents the hypothetical relationship between the variables. The path coefficient has an approximate normalized value between -1 and +1 . The path coefficient approaching +1 represents a strong positive relationship, and vice versa; the closer to zero the relationship between the two research variables is, the weaker the relationship is. (Hair et al., 2017).

Fifth, the authors employed the Bootstrap 1000 technique. This is to evaluate the significance of the path coefficients. At the $5 \%$ level of significance, if the p-value is less than 0.05 , it indicates that the effects in the model are all significant and vice versa.

\section{Research Results}

\subsection{Evaluation of the reliability and convergence value of the scale}

The reliability of the scales for all research variables is presented in Table 2 . The results show that the Composite Reliability (CR) of the research variables ranges from 0.874 to 0.941 and is higher than the minimum threshold of 0.70 . The coefficients 
of Cronbach's Alpha (CA) of the research variables are also greater than the minimum threshold of 0.70 (ranging from 0.809 to 0.928 ), proving that the scales have high reliability. In addition, the Average Variance Extracted (AVE) values are all 0.635 or higher, which is higher than the minimum threshold of 0.50 . Therefore, it can be concluded that the scales for the research variables are fully convergent.

Table 2

The results of the evaluation of the reliability and convergence value of the scale

\begin{tabular}{lcc}
\multicolumn{1}{c}{ Scale } & CA & CR \\
\hline Teaching methods for IFRS training (X_1) & 0.888 & 0.917 \\
Regulations of Ministry of Finance on the application of IFRS (X_2) & 0.902 & 0.938 \\
Faculty/ Institution administrators (X_3) & 0.893 & 0.690 \\
Training programs (X_4) & 0.905 & 0.933 \\
Teaching aids (X_5) & 0.820 & 0.934 \\
Learners (students, trainees) (X_6) & 0.839 & 0.889 \\
Institution's financial ability (X_7) & 0.877 & 0.892 \\
Teaching staff (X_8) & 0.919 & 0.923 \\
Requirements from related parties (X_9) & 0.809 & 0.939 \\
Applying IFRS to teaching accounting and auditing majors (Y) & 0.928 & 0.779 \\
\hline
\end{tabular}

\subsection{Evaluation of the scale discriminant value}

The authors evaluated the discriminant value of the scales through the criteria of the Fornell-Larcker coefficient and the HTMT coefficient. The results obtained are as follows:

First, about the Fornell-Larcker coefficient

Table 3

The results of the evaluation of discriminant value by Fornell-Larcker's criteria

\begin{tabular}{ccccccccc}
\hline & X_1 & X_2 & X_3 & X_4 & X_5 & X_6 & X_7 & X_8 \\
\hline X_1 & $\mathbf{0 . 8 3 1}$ & & & & & & & \\
X_2 & 0.470 & $\mathbf{0 . 9 1 4}$ & & & & & \\
X_3 & 0.497 & 0.534 & $\mathbf{0 . 9 0 8}$ & & & & \\
X_4 & 0.416 & 0.445 & 0.425 & $\mathbf{0 . 8 8 3}$ & & & \\
X_5 & 0.402 & 0.437 & 0.375 & 0.313 & $\mathbf{0 . 8 5 3}$ & & \\
X_6 & 0.263 & 0.380 & 0.355 & 0.231 & 0.277 & $\mathbf{0 . 8 2 1}$ & & \\
X_7 & 0.400 & 0.368 & 0.298 & 0.239 & 0.305 & 0.199 & $\mathbf{0 . 8 9 5}$ & \\
X_8 & 0.438 & 0.492 & 0.405 & 0.422 & 0.278 & 0.281 & 0.309 & $\mathbf{0 . 8 7 0}$ \\
X_9 & 0.369 & 0.392 & 0.299 & 0.324 & 0.396 & 0.189 & 0.364 & 0.250 \\
Y & 0.558 & 0.677 & 0.582 & 0.638 & 0.492 & 0.406 & 0.339 & 0.625 \\
\hline & & & & & & & (Source: Data analysis results from SmartPLS 3 software)
\end{tabular}

The results of Table 3 show that the square root of the Average Variance Extracted ( $\sqrt{A V E})$ (figures located on the diagonal, bold) of the variables are from 0.797 or more and larger than the correlation coefficient of the variables (the corresponding figures not in bold, in the same column of variables). Thus, the scales satisfy Fornell-Larcker criteria to get discriminant value.

\section{Second, about the HTMT coefficient}

The authors continued to evaluate the discriminant value of the scale by using the HTMT coefficient. Table 4 shows that the values of HTMT coefficients range from 0.234 to 0.594 , which is less than the threshold of 0.90 (Henseler et al., 2015; Hair et al., 2019). With the above analysis results, it is proved that the scale for the variables in the research model has the discriminant value. Thus, the scales for the research variables have reliability, ensure convergent value as well as discriminant value. Therefore, the collected data can be well adopted to test the research hypotheses.

Table 4

The results of the evaluation of the discriminant value of the scale by the HTMT coefficient

\begin{tabular}{|c|c|c|c|c|c|c|c|c|c|c|}
\hline & X_1 & X_2 & X_3 & X_4 & X_5 & X_6 & X_7 & X_8 & X_9 & $\mathbf{Y}$ \\
\hline \multicolumn{11}{|l|}{ X_1 } \\
\hline X_z & 0.515 & & & & & & & & & \\
\hline X_3 & 0.555 & 0.594 & & & & & & & & \\
\hline X_4 & 0.456 & 0.486 & 0.467 & & & & & & & \\
\hline X_5 & 0.447 & 0.482 & 0.405 & 0.337 & & & & & & \\
\hline X_6 & 0.288 & 0.420 & 0.408 & 0.264 & 0.297 & & & & & \\
\hline X_7 & 0.453 & 0.415 & 0.336 & 0.265 & 0.367 & 0.234 & & & & \\
\hline X_8 & 0.468 & 0.537 & 0.441 & 0.447 & 0.290 & 0.298 & 0.341 & & & \\
\hline X_9 & 0.436 & 0.458 & 0.352 & 0.374 & 0.483 & 0.221 & 0.431 & 0.285 & & \\
\hline $\mathbf{Y}$ & 0.598 & 0.733 & 0.641 & 0.690 & 0.530 & 0.447 & 0.372 & 0.666 & 0.523 & \\
\hline
\end{tabular}


The test results show that the independent variables X 1, X 2, X 3, X 4, X 5, X 6, X 8, X 9 all have a direct and positive influence on $Y$ (because the p-values of the t-test of the variables are all less than $5 \%$ ). In details, the order of decreasing impact of variables on $\mathrm{Y}$ is as follows: X_4, X_8, X_2, X_9, X_3, X_5, X_1 and X_6. Variable X7 has no effect on Y because pvalue is $0.342>0.05$

Table 5

The results of testing the hypotheses about the relationship

\begin{tabular}{ccc}
\hline Research variables & Testing results & Coefficient $\beta$ \\
\hline X_1 & 0.084 & 0.044 \\
X_2 & 0.227 & 0.003 \\
X_3 & 0.113 & 0.038 \\
X_4 & 0.270 & 0.000 \\
X_5 & 0.109 & 0.025 \\
X_6 & 0.082 & 0.023 \\
X_7 & -0.043 & 0.342 \\
X_8 & 0.249 & 0.019 \\
X_9 & 0.112 & 0.045 \\
\hline
\end{tabular}

(Source: Data analysis results from SmartPLS 3 software)

From the results in Table 5, the regression model of factors affecting the application of IFRS in teaching can be rewritten as follows:

$$
Y=0.270 * X \_4+0.249 * X \_8+0.227 * X_{-} 2+0.112 * X \_9+0.113 * X \_3+0.109 * X \_5+0.084 * X \_1+0.082 * X \_6-
$$

The model of the impact levels of the factors through the analysis of PLS Algorithm and Bootstrap 1.000 is as follows:
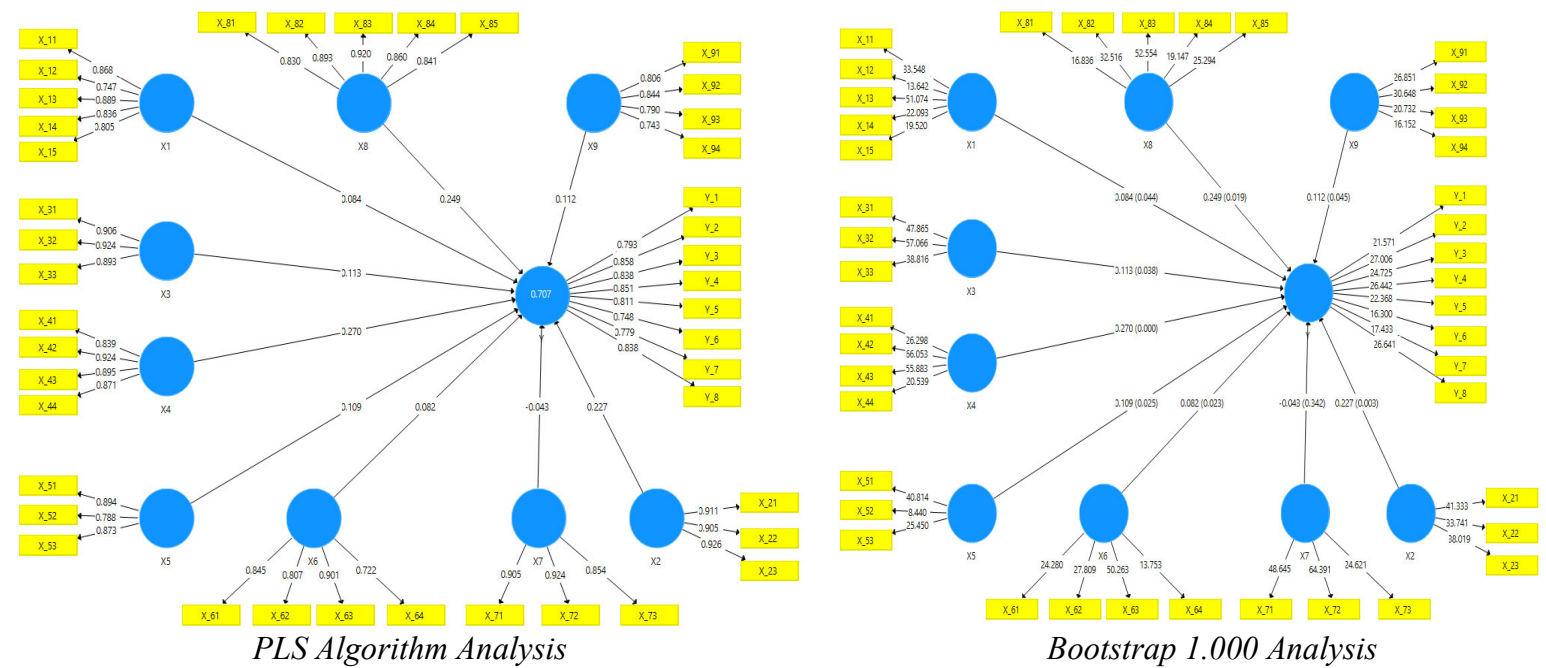

\section{Discussion and policy implications}

Fig. 3. The summary of the analysis

From the results of the regression analysis, the order of factors affecting the application of IFRS in teaching is (i) Training programs; (ii) Teaching staff; (iii) Regulations of Ministry of Finance on the application of IFRS; (iv) Requirements from related parties; (v) Faculty/Institution administrator; (vi) Teaching aids; (vii) Teaching methods for IFRS training and (viii) learners (students, trainees). Basically, the results of this study are quite consistent and similar to the research results of some researchers mentioned in the literature overview and research hypotheses.

Therefore, according to the results of this study, the authors believe that applying IFRS to teaching at universities and colleges in Vietnam to meet the regulations by the Ministry of Finance on the application of IFRS and requirements from related parties in recruiting accounting and auditing staff, requires institutions to carry out the following tasks: (i) The institutions need to quickly renew and update training programs through the integration of IFRS knowledge into the current training programs; it is possible to impart IFRS knowledge through accounting modules and integrate and teach IFRS in parallel with the knowledge of accounting standards, national accounting regime, or to convey knowledge about IFRS in a separate module so that learners can highlight the differences between national accounting regime and IFRS. At the same time, in order to agree on the content and knowledge of IFRS to be taught in schools nationwide, the Ministry of Education 
and Training needs to coordinate with the Ministry of Finance to issue common frameworks on training programs for the majors of accounting, auditing; in which, there is a regulation on the level of capacity, the learning outcome for the IFRSrelated knowledge so that the institutions can easily put into use when updating training programs; (ii) The institutions need to organize training courses on IFRS knowledge for lecturers in charge of IFRS-related modules, coordinate with professional organizations and associations such as ACCA to foster knowledge about IFRS for lecturers; (iii) Faculty/Institution administrators are in need of actively supporting and creating all favorable conditions in terms of policy, finance, application roadmap, etc.; (iv) The institutions are required to promote investment in teaching aids, including the compilation of lectures, learning materials, enhancing information technology infrastructure, etc. to facilitate the teaching and learning process; (v) The lecturers are encouraged to change their views regarding the teaching methodology, transforming the teaching methods from presentation to case handling, simulation of reality, etc.; (vi) It is necessary to inform learners of future job opportunities when acquiring IFRS knowledge so that they can be fully aware of IFRS learning and adjust their self-study and self-research behaviors accordingly.

\section{Conclusion}

This study has identified eight factors affecting the application of IFRS in teaching at universities and colleges in Vietnam, including internal factors of the institutions such as training programs, teaching staff, faculty/institution administrators, teaching aids, teaching methods for IFRS training and external factors such as the Ministry of Finance's IFRS application regulations, requirements from the related parties, learners. Therefore, to meet the requirements of the Ministry of Finance, stakeholders and learners' needs, it is required that institutions quickly innovate and update training programs through the integration of knowledge of IFRS in the training programs being taught, organize training courses on IFRS knowledge for lecturers, invest in teaching aids. The faculty/institution administrators are supposed to actively support and create all favourable conditions in terms of policy, finance, application roadmap, etc. to put IFRS into teaching as soon as possible. With the above research results, the authors believe that this study can make important contributions to providing scientific arguments to incentivize universities and colleges in Vietnam in identification and application in reality in the process of applying IFRS into teaching.

\section{Acknowledgement}

This study was carried out within the framework of a ministerial-level science and technology project under the chair of Quy Nhon University with the code: B2020-DQN-07.

\section{References}

Ackermann, F., \& Eden, C. (2011). Strategic Management of Stakeholders: Theory and Practice. Long Range Planning, 44(3), 179-196. https://doi.org/10.1016/j.lrp.2010.08.001.

Al-Shetwi, M. (2021). Determinants of corporate social disclosure in Saudi Arabia: The role of social values and IFRS convergence.Accounting, 7(7), 1769-1778.

Al-Sakini, S., Awawdeh, H., Awamleh, I \& Qatawneh, A. (2021). Impact of IFRS (9) on the size of loan loss provisions: An applied study on Jordanian commercial banks during 2015-2019.Accounting, 7(7), 1601-1610.

Alzeban, A. (2016). Factors influencing adoption of the international financial reporting standards (IFRS) in accounting education. Journal of International Education in Business, 9, 1-22. http://dx.doi.org/10.1108/JIEB-10-2015-0023

Bagozzi, R. P., Yi, Y., \&Nassen, K. D. (1988). Representation of measurement error in marketing variables: Review of approaches and extension to three - facet designs. Journal of Econometrics, 89(1-2), 393 - 421.

Beasley, M., Clune, R., \& Hermanson, D. (2005). Enterprise risk management: An empirical analysis of factors associated with the extent of implementation. Journal of Accounting and Public Policy, 24(6), 521-531. https://doi.org/10.1016/j.jaccpubpol.2005.10.001

Belyaeva, I. G., Samorodova, E. A., Voron, O. V., \& Zakirova, E. S. (2019). Analysis of Innovative Methods' Effectiveness in Teaching Foreign Languages for Special Purposes Used for the Formation of Future Specialists' Professional Competencies. Educ. Sci, 9, 171. https://doi.org/10.3390/educsci9030171

Braun, R. L., Boldt, M. N., Mauldin, S. \& Viosca, C. (2020). Accounting graduates with both online and traditional coursework: impact on hiring decisions. Accounting Education, 29(4), 340-355. https://doi.org/10.1080/09639284.2020.1788613

Bruce, G. C., Edward, F., Crawleyb, G. L., Eric S. R. (2008). Value flow mapping: Using networks to inform stakeholder analysis. Acta Astronautica, 62 (2008), $324-333$.

Bourne, L. M., \& Walker, D. H. (2005). Visualising and mapping stakeholder influence. Management Decision, 43, 649660.

Bruns, S. M. (2014). Accounting Integration Issues: From AECC to Pathways and Beyond. Advances in Accounting Education: Teaching and Curriculum Innovations, 15, 127-134. https://doi.org/10.1108/S1085-462220140000015005

Convey, J. J. (2012). Perceptions of Catholic Identity: Views of Catholic School Administrators and Teachers. Journal of Catholic Education, 16 (1). http://dx.doi.org/10.15365/-joce.1601102013 
Chiang, B. (2014). Self-Directed Learning: Using Individualized Self-Directed Learning Assignments in a Managerial Accounting Course, Advances in Accounting Education: Teaching and Curriculum Innovations, 15, 79101. https://doi.org/10.1108/S1085-462220140000015008

Chin, W. W., 2010. How to Write Up and Report PLS Analyses. In: V. E. Vinzi, W. W. Chin, J. Henseler, \& H. Wang, Ed. 2010. Handbookof Partial Least Squares: Concepts, Methods and Applications Berlin, German: Springer, 655-690.

De Lima, V. S., De Lima, G. A. S. F., \& Gotti, G. (2018). Effects of the adoption of IFRS on the credit market: evidence from Brazil. The International Journal of Accounting, 53(2), 77-101. https://doi.org/10.1016/j.intacc.2018.04.001

Devellis, R. (2012). Scale Development Theory and Applications. Sage Publications, New York.

Dow K. J., \& Feldmann, D. A. (1997). Current approaches to teaching intermediate accounting. Issues in Accounting Education, 12, 61-75.

El-Ariss, B., Zaneldin, E., Ahmed, W. (2021). Using Videos in Blended E-Learning for a Structural Steel Design Course. Education Science, 11, 290. https://doi.org/10.3390/-educsci11060290

Eric, A. H. (1996). Measuring Investment in Education. Journal of Economic Perspectives, 10(4), 9-30.

Fogarty, T. J., \& Jonas, G. A. (2019). The Goldilocks Relationship between Exam Completion Sequencing and Performance in Accounting Classes. Advances in Accounting Education: Teaching and Curriculum Innovations, 22, 89107. https://doi.org/10.1108/S1085-462220190000022005

Fornell, C. \& Larcker, D. F., 1981. Structural equation models with unobservable variables and measurement error: Algebra and statistics. Journal of Marketing Research, 18(3), 382-388.

Freeman, R. E. (1984), Strategic Management, A Stakeholder Approach, Pitman Series in Business and Public Policy. Harpercollins College Div; First edition (January 1, 1984).

Garnett, R. P. (2011). The role of the framework in IFRS interpretation. Presentation to the Joint IAA IFRS Foundation IFRS Teaching Special Interest Session (June 27). Fancourt, George, South Africa

Hair, J. F., Hult, G. T. M., Ringle, C. M., et al., 2014. A primer on partial least squares structural equation modeling (PLSSEM). USA: SAGE Publications.

Hair, J. F., Hult, G. T. M., Ringle, C. M., et al., 2017. A Primer on Partial Least Squares Structural Equation Modeling (PLS-SEM). USA: SAGE Publications.

Hair, J. F., Risher, J. J., Sarstedt, M., et al., 2019. When to use and how to report the results of PLS-SEM. European Business Review, 31(1), 2-24.

Henseler, J. \& Sarstedt, M., 2013. Goodness - of - fit indices for partial least squares path modeling . Computational Statistics, 28, 565-580.

Henseler, J., Ringle, C. M. \& Sarstedt, M. (2015). A new criterion for assessing discriminant validity in variance-based structural equation modeling. Journal of the Academy of Marketing Science, 43, 115-135. https://doi.org/10.1007/s11747-014-0403-8

Hilton, S., \& Johnstone, N. (2013). The IFRS transition and accounting Education: a Canadian perspective post-transition. Issues in Accounting Education, 28(2), 253-261. http://dx.doi.org/10.2308/iace-50366

Jackling, B, De Lange, P. A. \& Natoli, R. (2013). Transitioning to IFRS in Australian classrooms: impact on teaching approaches. Issues in Accounting Education, 28(2), 263-275. http://dx.doi.org/10.2308/iace-50358.

Joshua, A., Kalifeh. (2017). IFRS in Higher Education: An Exploratory Study. The University of Southern Mississippi, Honors Teses. 475. Available at: htp://aquila.usm.edu/honors theses/475

Kang, G., Liu, X., \& Hsiao, D. (2016). Are We Ready for the Changes in U.S. Accounting Standards? Some Evidence of Midwestern Universities Curriculum. Journal of Accounting - Business \& Management, 23(1), 1-14.

Krasodomska, J. \& Godawska, J. (2021). E-learning in accounting education: the influence of students' characteristics on their engagement and performance. Accounting Education, 30(1), 22-41. https://doi.org/10.1080/09639284.2020.1867874

Le The Anh. (2017). Discussing accounting training methods according to international financial reporting standards. Journal of Dai Nam University. Available at: http://dainam.edu.vn/en/tin-tuc/trao-doi-ve-phuong-phap-dao-tao-ketoan-theo-chuan-muc-bao-cao-tai-chinh-quoc-te

López-Díaz, M. T., Peña, M. (2021). Mathematics Training in Engineering Degrees: An Intervention from Teaching Staff to Students. Mathematic, 9, 1475. https://doi.org/-10.3390/math 9131475

Mellado, L., Parte, L., \& Villanueva, E. (2020). Perceptions of the accounting profession based on an analysis of metaphors by undergraduate accounting students. Accounting Education, 29(6), 572604. https://doi.org/10.1080/09639284.2020.1833227

Ministry of Education and Training. (2021). Circular No. 17/2021/TT-BGDĐT, issued on June 22, 2021, on standards of training programs; formulating, appraising and promulgating training programs at higher education levels. Hanoi.

Ministry of Finance. (2016). Decision No. 345/QD-BTC on approving the Scheme on the application of financial reporting standards in Vietnam, issued on March 16, 2020. Hanoi.

Mitchell, R. K., Agle, B. R., \& Wood, D. J. (1997). Toward a Theory of Stakeholder Identification and Salience: Defining the Principle of Who and What Really Counts. The Academy of Management Review, 22(4), 853-886. https://doi.org/10.2307/259247

Mkhongi, F.A., Musakwa, W. (2020). Perspectives of GIS Education in High Schools: An Evaluation of uMgungundlovu District, KwaZulu-Natal, South Africa. Educational Science, 10, 131. https://doi.org/10.3390/educsci10050131 
Munter, P., \& Reckers, P. (2009). IFRS and collegiate accounting curricula in the United States: 2008 a survey of the current state of education conducted by KPMG and the Education Committee of the American Accounting Association. Issues in Accounting Education, 24(2), 131-139. https://doi.org/10.2308/iace.2009.24.2.131.

Nanyan, D., Bai, M., Zhang, H., \& Zhang, J. (2019). Approaches to learning IFRS by Chinese accounting students. Journal of Accounting Education, Available at: https://doi.org/10.1016/j.jaccedu.2019.04.002

National Assembly. (2018). Law No. 34/2018/QH18 on the Law on amending and supplementing a number of articles of the Law on Higher Education. Hanoi.

Nguyen Cuu Dinh. (2017). Introducing IFRS into accounting training programs of Vietnamese universities. Proceedings of the Workshop "IFRS - Opportunities and challenges when applied in Vietnam, 247-255.

Parvathy, P. R. (2017). IFRS convergence: opportunities and challenges in India. Accounting and Financial Control, 1(2), 13-18.

Pham Thi Tuyet Minh. (2019). Renovating accounting and auditing training at Vietnamese universities in the context of economic integration. Proceedings of the conference "Vietnamese Accounting - Future and Prospects", 144-148

Robert, K. L., \& Donna, L. S. (2011). IFRS Teaching Resources: Available and Rapidly Growing. Accounting Education, 20(4), 317-338. https://doi.org/10.1080/09639284.20-11.583795

Rothstein, J. (2017). Measuring the impact of teachers: Comment. American Economic Review 107 (6), $1656-1684$.

Rouse, C. E., \& Barrow, L. (2009). School vouchers and student achievement: Recent evidence and remaining questions. Annual Review of Economics, 17-42.

Seifan, M., Dada, O. D., Berenjian, A. (2020). The Effect of Real and Virtual Construction Field Trips on Students' Perception and Career Aspiration. Sustainability, 12, 1200. https://doi.org/10.3390/su12031200

Susan, M., Albring, R., Elder, J. (2020). Research Initiatives in Accounting Education: Managing Academic Programs. Issues in Accounting Education, 35(4), 61-74. doi: https://doi.org/10.2308/ISSUES-2020-020

Szwarc, E., Wikarek, J., Gola, A., Bocewicz, G., Banaszak, Z. (2020). Interactive Planning of Competency-Driven University Teaching Staff Allocation. Applied Sciences, 10, 4894. https://doi.org/10.3390/app10144894

Ta, T. T., Pham, D. C., Nguyen, H. A., Doan, T. N., Dinh, T. H., Do, H. G., \& Pham, H. T. (2021). Factors Affecting the Adoption of IFRS: The Case of Listed Companies on Ho Chi Minh Stock Exchange. Journal of Asian Finance, Economics and Business, 8(2), 873-882. https://doi:10.13106/jafeb.2021.vol8.no2.0873

Tami, A. M., Bika-Lele, E. C., Mekoulou-Ndongo, J., Ayina-Ayina, C.N., Guessogo, W.R., Lobe Tanga, M.-Y., Owona Manga, L.J., Temfemo, A., Bongue, B., Mandengue, S.H. (2021). Epidemiology of Musculoskeletal Disorders among the Teaching Staff of the University of Douala, Cameroon: Association with Physical Activity Practice. Int. J. Environ. Res.Public Health, 18, 6004. https://doi.org/10.3390/ijerph18116004.

Turhan, M., Şengür, D., Karabatak, S., Guo, Y., Smarandache, F. (2018). Neutrosophic Weighted Support Vector Machines for the Determination of School Administrators Who Attended an Action Learning Course Based on Their ConflictHandling Styles. Symmetry, 10, 176. https://doi.org/10.3390/sym10050176.

Thomas, D., \& Lee, E. P. (1995). The Stakeholder Theory of the Corporation: Concepts, Evidence, and Implications. The Academy of Management Review, 20(1), 65-91.

Tran Manh Dung \& Nguyen Thuy Hong. (2016). Teaching IFRS in accounting training. Journal of Accounting \& Auditing, 150, 15-17.

Tran, T., Ha, X., Le, T., \& Nguyen, N. (2019), Factors affecting IFRS adoption in listed companies: Evidence from Vietnam. Management Science Letters, 9(13), 2169-2180. https://doi. org/10.5267/j.msl.2019.7.035.

Trinh Duc Vinh. (2019). Skills - knowledge accountants need to be equipped to meet the requirements of accounting innovation in Vietnam. Proceedings of the Vietnam Accounting Conference - Future and Prospects, 22-23.

Zhu, H., Rich, K., Michenzi, A., \& Cherubini, J. (2011). User-oriented IFRS education in introductory accounting at U.S. academic institutions: current status and influencing factors. Issues in Accounting Education, 26(4), 725-750. https://doi.org/10.2308/iace-50058.

Valenzuela, J. P., Bellei, C., \& Ríos, D. D. L. (2014). Socioeconomic school segregation in a market-oriented educational system. The case of Chile. Journal of Education Policy, 29(2), 217-241.

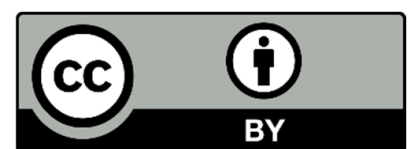

(C) 2022 by the authors; licensee Growing Science, Canada. This is an open access article distributed under the terms and conditions of the Creative Commons Attribution (CC-BY) license (http://creativecommons.org/licenses/by/4.0/). 